\title{
Cultured and genetic diversity, and activities of sulfur-oxidizing bacteria in low-temperature hydrothermal fluids of the North Fiji Basin
}

\author{
Lilijana Podgorsek ${ }^{1}$, Ralf Petri ${ }^{1,2}$, Johannes F. Imhoff ${ }^{1, *}$ \\ ${ }^{1}$ Institut für Meereskunde, Düsternbrooker Weg 20, 24105 Kiel, Germany
}

${ }^{2}$ Present address: Department of Biochemistry, University of Minnesota, 1479 Gortner Ave., St. Paul, Minnesota 55108, USA

\begin{abstract}
We determined key chemical parameters and thiosulfate oxidation in low-temperature hydrothermal fluids from the North Fiji Basin. In addition, the bacterial diversity (with the main emphasis on sulfur-oxidizing bacteria) was investigated. The hydrothermal fluids had low concentrations of sulfide (up to $50.0 \mu \mathrm{M}$ ) and increased counts of both total bacteria and sulfur-oxidizing bacteria compared to ambient seawater. Pure cultures of bacteria were isolated from these fluids on media suited for autotrophic, and potentially heterotrophic, sulfur-oxidizing bacteria. Evidence for the abundance of $\alpha$ - and $\gamma$-Proteobacteria was obtained from identification of isolated pure cultures. A large number of $16 \mathrm{~S}$ rDNA sequences of these groups were retrieved from environmental DNA. Representatives of the Cytophaga-Flavobacterium phylum were found by denaturing gradient gel electrophoresis (DGGE) and 16S rDNA sequence information of DGGE bands, although these bacteria could not be isolated with the media used in this study. Evidence for the presence of chemolithoautotrophic sulfur-oxidizing bacteria was found by analysis of environmental DNA, using 16S rDNA-specific primers of various groups of chemotrophic sulfur bacteria. They were isolated in low numbers compared to chemoheterotrophic and mixotrophic sulfur-oxidizing bacteria. In addition, the formation of tetrathionate as major oxidation product of thiosulfate added to hydrothermal fluid samples and to pure cultures of new isolates indicates the importance of chemoheterotrophic sulfur-oxidizing bacteria within the warm vent waters investigated during this study.
\end{abstract}

KEY WORDS: Hydrothermal vents · Thiosulfate oxidation · Sulfur bacteria · Bacterial diversity

\section{INTRODUCTION}

Hydrothermal vents are known to support chemolithoautotrophic life due to the presence of reduced inorganic electron donors for bacterial energy generation and the presence of $\mathrm{CO}_{2}$ and methane as carbon sources. Early microbiological studies of hydrothermal vents have focussed on the isolation of hyperthermophilic and thermophilic archaea and bacteria, and on chemolithotrophic bacteria, in particular sulfur bacteria, either free-living or in symbioses with a specialized vent fauna (Jannasch 1989). Numerous studies deal with symbiotic associations of bacteria with the vent fauna (Nelson \& Fisher 1995, Jeanthon 2000,
Imhoff et al. 2003), and with the isolation and characterization of (hyper)thermophilic bacteria and archaea from extremely hot vents (Baross \& Deming 1995, Reysenbach et al. 2000). Many bacterial isolates characterized from hydrothermal vent environments are chemolithoautotrophic bacteria representing initial settlement on hard substrates or within the sediment (Gunderson et al. 1992, Gugliandolo \& Maugeri 1993, Moyer et al. 1994, Muyzer et al. 1995, Mattison et al. 1998, Brinkhoff et al. 1999, Taylor et al. 1999). In more recent studies, 16S rDNA-based approaches have also been applied to study the bacterial diversity at hydrothermal habitats, such as hydrothermally influenced Aegean sediments, and vent chimneys on the 


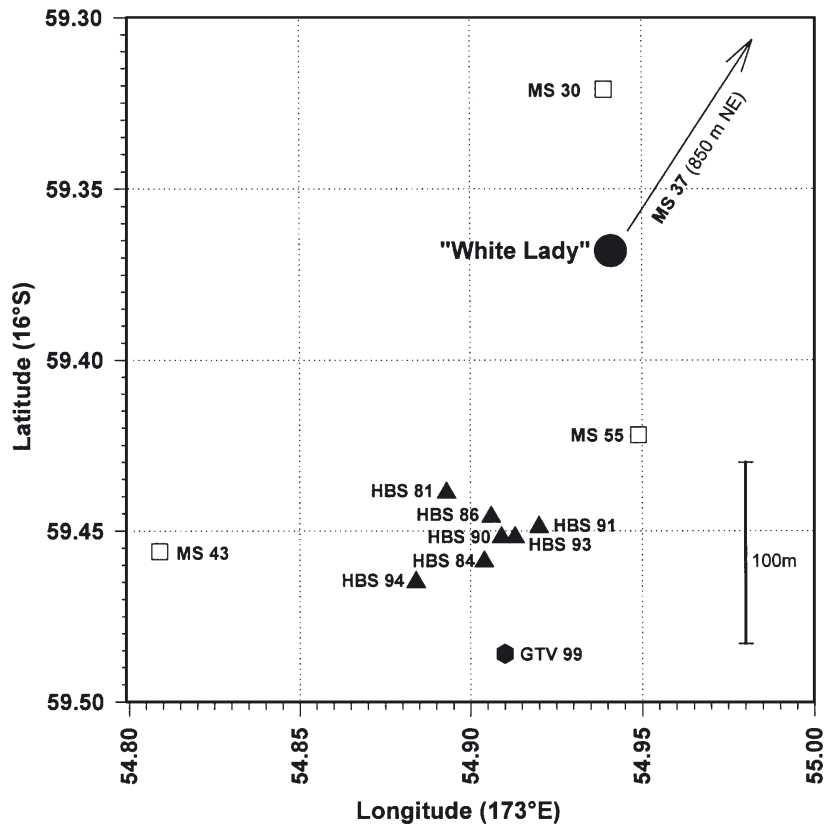

Fig. 1. Position of stations sampled with the Hydro Bottom Station (HBS, $\mathbf{\Delta}$ ), with Niskin bottles attached to a multisonde (MS, 口) and with a TV grab (GTV, $)$, and location of the white smoker 'White Lady' (•)

East Pacific Rise (Moyer et al. 1994, Muyzer et al. 1995, Polz \& Cavanaugh 1995, Brinkhoff et al. 1999, Sievert et al. 1999, Jeanthon 2000). Diffuse-flow hydrothermal fluids and hydrothermal plumes from deep-sea vents have received less attention (Winn \& Karl 1986, Naganuma et al. 1989, Karl 1995).

In this study, we investigated the diversity and activity of sulfur-oxidizing bacterial communities of low temperature hydrothermal vent fluids from the North Fiji Basin, which is a tectonic spreading zone with divergence rates of 5 to $8 \mathrm{~cm} \mathrm{yr}^{-1}$. It consists of a volcanic dome, which is located in a 1980 to $2200 \mathrm{~m}$ deep and $2 \mathrm{~km}$ wide valley, bounded by $100 \mathrm{~m}$ high ridges (Halbach et al. 1999, Koschinsky et al. 2002). The endmember fluids are separated into 2 phases: (1) a condensed-vapor phase with low amounts of heavy metals and salinity, and (2) a concentrated brine phase with high concentrations of metals and salinity (Butterfield et al. 1997, Halbach et al. 2001). Hydrothermal plumes could be detected in the water column up to $100 \mathrm{~m}$ above the sea floor. Previous work provided information on bacterial abundance and on growth rates of bacteria isolated from plumes and hydrothermal fluids in this area (Durand et al. 1994, Naganuma \& Seki 1994). However, molecular genetic approaches on the composition of the bacterial communities from hydrothermal vent sites in the North Fiji Basin are lacking.

\section{MATERIALS AND METHODS}

Habitat. The 'LHOS' field is located in a rift valley of the North Fiji Basin and characterized by several small sites and one large site with low-temperature hydrothermal activity. Plumes were detected within $2 \mathrm{~km}$ distance around the high-temperature white smoker 'White Lady' $\left(290^{\circ} \mathrm{C}\right.$; Fig. 1, Table 1). Fauna was present in patches on the seafloor, with up to 300 mussels and gastropods per $\mathrm{m}^{2}$, dominated by Bathymodiolus brevior and Ifremeria nautilei. These settlements were concentrated around highly fractured basaltic mounds, which rose ca. $1 \mathrm{~m}$ above the sea floor. The mounds, 1 to $2 \mathrm{~m}$ in diameter, were located on young fissures in the seafloor with widths of several $\mathrm{cm}$ to $\mathrm{dm}$. The emanating hydrothermal fluids were characterized by a pulsating outflow (rhythm of 2 to $6 \mathrm{~min})$, low emission temperatures $\left(<13^{\circ} \mathrm{C}\right)$ and reducing conditions. Sulfide and methane (see Table 1 and Fig. 2), as well as oxygen, were present in these fluids. Calculations from end-member fluid models gave a mixing ratio of ca. 33 parts seawater to 1 part original hydrothermal fluid (Butterfield et al. 1997, Halbach et al. 2001).

Sampling. Samples were taken during the research cruise with RV 'Sonne' SO 134 in August 1998 in the

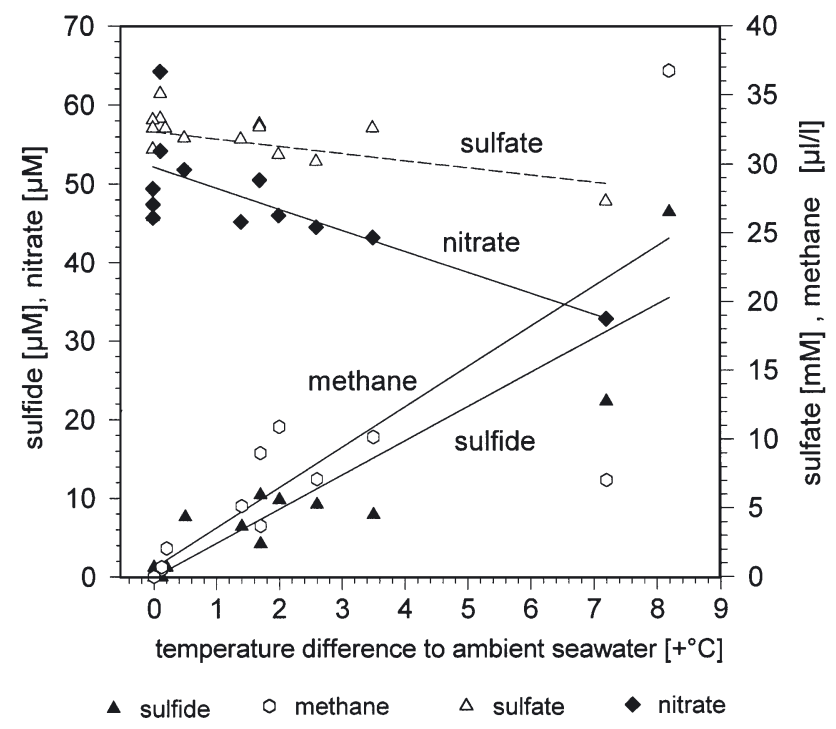

Fig. 2. Concentrations of parameters from different plume and ground stations, relevant in the determination of the hydrothermal character of fluids in relation to the temperature difference from ambient deep-sea waters $\left(2.25^{\circ} \mathrm{C}\right)$ in the North Fiji Basin. Increasing concentrations of sulfide, and decreasing concentrations of sulfate and nitrate indicate the hydrothermal impact. Values for methane concentrations are from R. Seifert (University of Hamburg, pers. comm.). Regression lines were calculated by Sigma Plot, Release 3.0 
Table 1. Important parameters of fluid samples from sampling stations in the North Fiji Basin. Samples from plumes were taken with Niskin bottles attached to a CTD probe (multisonde, MS), samples directly above the ground with the Hydro Bottom Station (HBS), and samples from clams were taken with a TV grab (GTV). The temperature difference $\left(\Delta^{\circ} \mathrm{C}\right)$ relative to background temperature of ambient seawater $\left(2.25^{\circ} \mathrm{C}\right)$, presence of sulfide and elevated methane concentrations demonstrate the hydrothermal origin of the samples. Methane was measured by R. Seifert, University of Hamburg, with a background maximum of $0.13 \mathrm{nM}$; SOB: sulfur-oxidizing bacteria; n.m.: not measured

\begin{tabular}{|c|c|c|c|c|c|c|c|c|}
\hline Station & $\begin{array}{l}\text { Latitude } \\
\left({ }^{\circ} \mathrm{S}\right)\end{array}$ & $\begin{array}{l}\text { Longitude } \\
\qquad\left({ }^{\circ} \mathrm{E}\right)\end{array}$ & $\begin{array}{l}\text { Water depth } \\
\qquad(\mathrm{m})\end{array}$ & $\begin{array}{l}\text { Distance to } \\
\text { ground }\end{array}$ & $\begin{array}{c}\text { Temperature } \\
\left(\Delta^{\circ} \mathrm{C}\right)\end{array}$ & $\begin{array}{l}\text { Sulfide } \\
(\mu \mathrm{M})\end{array}$ & $\begin{array}{l}\text { Methane } \\
\text { (nM) }\end{array}$ & $\begin{array}{c}\text { SOB } \\
\left.\text { (counts } 10^{6} \mathrm{l}^{-1}\right)\end{array}$ \\
\hline \multicolumn{9}{|l|}{ Plume } \\
\hline MS 30/1 & $16^{\circ} 59.292^{\prime}$ & $173^{\circ} 54.781^{\prime}$ & 1974 & $3 \mathrm{~m}$ & 0 & 0 & 1.2 & 4.0 \\
\hline MS 30/5 & & & 1873 & $104 \mathrm{~m}$ & 0 & 0 & n.m. & 2.9 \\
\hline MS 37/1 & $16^{\circ} 59.102^{\prime}$ & $173^{\circ} 55.395^{\prime}$ & 1936 & $1 \mathrm{~m}$ & 0 & 0 & 1.1 & 2.9 \\
\hline MS 37/2 & & & 1925 & $12 \mathrm{~m}$ & 0 & 0 & 1.1 & 1.2 \\
\hline MS 43/2 & $16^{\circ} 59.430^{\prime}$ & $173^{\circ} 54.930^{\prime}$ & 1987 & $1 \mathrm{~m}$ & 0.12 & 0 & 39.0 & 4.3 \\
\hline MS 43/4 & & & 1969 & $20 \mathrm{~m}$ & 0 & 0 & 0.8 & 1.5 \\
\hline MS 55/11 & $16^{\circ} 59.422^{\prime}$ & $173^{\circ} 54.949^{\prime}$ & 1929 & $42 \mathrm{~m}$ & 0.1 & 0 & 9.7 & 0.24 \\
\hline MS 55/15 & & & 1899 & $72 \mathrm{~m}$ & 0.1 & 0 & 7.4 & 1.1 \\
\hline \multicolumn{9}{|l|}{ Ground } \\
\hline HBS 81 & $16^{\circ} 59.439^{\prime}$ & $173^{\circ} 54.893^{\prime}$ & & Ground & 0.12 & 0 & 30.8 & 0.15 \\
\hline HBS 84 & $16^{\circ} 59.459^{\prime}$ & $173^{\circ} 54.904^{\prime}$ & & Ground & 1.7 & 4.20 & 159.4 & 0.07 \\
\hline HBS 86/1 & $16^{\circ} 59.446^{\prime}$ & $173^{\circ} 54.906^{\prime}$ & & Ground & 2.0 & 9.8 & 469.0 & 0.43 \\
\hline HBS $86 / 2$ & & & & $10 \mathrm{~cm}$ & 2.6 & 9.2 & 309.4 & 0.27 \\
\hline HBS 86/3 & & & & $20 \mathrm{~cm}$ & 1.4 & 6.4 & 221.6 & 0.13 \\
\hline HBS 86/4 & & & & $30 \mathrm{~cm}$ & 0.2 & 1.2 & 89.4 & 0.13 \\
\hline HBS 90 & $16^{\circ} 59.452^{\prime}$ & $173^{\circ} 54.909^{\prime}$ & & Ground & 3.5 & 7.9 & 437.2 & 0.61 \\
\hline HBS 91 & $16^{\circ} 59.449^{\prime}$ & $173^{\circ} 54.920^{\prime}$ & & $-5 \mathrm{~cm}$ & 1.7 & 10.4 & 387.1 & 0.53 \\
\hline HBS 93 & $16^{\circ} 59.452^{\prime}$ & $173^{\circ} 54.913^{\prime}$ & & $-5 \mathrm{~cm}$ & 0.5 & 7.6 & n.m. & 0.30 \\
\hline HBS 94/2 & $16^{\circ} 59.465^{\prime}$ & $173^{\circ} 54.884^{\prime}$ & & $45 \mathrm{~cm}$ & n.m. & 1.2 & 302.5 & n.m. \\
\hline HBS $94 / 4$ & & & & $5 \mathrm{~cm}$ & 7.2 & 22.3 & 1387.3 & n.m. \\
\hline HBS $94 / 6$ & & & & $-5 \mathrm{~cm}$ & 8.2 & 46.4 & 1580.3 & n.m. \\
\hline GTV 99 & $16^{\circ} 59.486$ & $173^{\circ} 54.910$ & & Ground $^{\mathrm{a}}$ & n.m. & n.m. & n.m. & n.m. \\
\hline
\end{tabular}

North Fiji Basin. Fluid samples from hydrothermal emission in the 'LHOS' field, ca. 200 m south-southwest of White Lady, were taken close to the seafloor (up to $40 \mathrm{~cm}$ from the ground) and directly within mussle beds on the seafloor. The Hydro Bottom Station (HBS), which was specifically developed for monitoring and sampling fluids directly from diffuse lowtemperature emanation sites (Halbach et al. 1999, Koschinsky et al. 2002), was used to take these samples. The distance between the different HBS-sampling sites amounted to some $100 \mathrm{~m}$. Niskin bottles attached to a multisonde (MS) as a rosette of 24 bottles of $10 \mathrm{l}$ volume were combined with a CTD and an oxygen sensor, and used to obtain samples of plume water. Samples of Bathymodiolus brevior were taken by a TV-guided grab. The coordinates of all sampling stations are listed in Table 1.

Bacterial reference strains and isolation of sulfuroxidizing bacteria (SOB). Three reference strains (Halothiobacillus hydrothermalis DSM 7121 ${ }^{\mathrm{T}}$, Paracoccus versutus DSM $582^{\mathrm{T}}$ and Thiomicrospira crunogena
DSM $12353^{\mathrm{T}}$ ) were obtained from the Deutsche Sammlung von Mikroorganismen und Zellkulturen (DSMZ, Braunschweig, Germany). They were used to verify the suitability of culture media and the applicability of PCR primers for analysis of SOB.

Bacteria were isolated from plume water and hydrothermal bottom water (taken with HBS) and from material scratched off from the outer shells of Bathymodiolus brevior from Stn GTV99 (GTV stations sampled with a TV-grab). Aliquots of the water samples were diluted in sterile artificial seawater MSM (see next paragraph below). From appropriate dilutions, $0.1 \mathrm{ml}$ were streaked on agar plates and incubated under aerobic conditions in the dark at $15^{\circ} \mathrm{C}$. Bacterial colonies were counted after 3 to 4 wk incubation. Isolation and purification of SOB was made by repeated dilution on agar plates with Thiobacilli standard media THSTh and THSTa, which proved to be suitable for the cultivation of the reference strains Paracoccus versutus (THSTh), Halothiobacillus hydrothermalis and Thiomicrospira crunogena (THSTa). 
For 11 of THSTa medium, the following components were separately sterilized, mixed after cooling, and adjusted to a final $\mathrm{pH}$ of 7.2. Solution A contained $250 \mathrm{ml}$ 4-fold concentrated artificial sea water MSM $\left(18.9 \mathrm{~g} \mathrm{NaCl}, 0.9 \mathrm{~g} \mathrm{MgCl}_{2} \times 6 \mathrm{H}_{2} \mathrm{O}, 0.8 \mathrm{~g} \mathrm{MgSO}_{4} \times\right.$ $7 \mathrm{H}_{2} \mathrm{O}, 0.53 \mathrm{~g} \mathrm{KCl}, 0.46 \mathrm{~g} \mathrm{CaCl}_{2} \times 2 \mathrm{H}_{2} \mathrm{O}, 0.07 \mathrm{~g} \mathrm{KBr}$ ); Solution B contained, in $250 \mathrm{ml}$ aqua dest, $0.1 \mathrm{~g} \mathrm{NH}_{4} \mathrm{Cl}$, $0.15 \mathrm{~g} \mathrm{KH}_{2} \mathrm{PO}_{4}$ and $0.8 \mathrm{~g} \mathrm{~K}_{2} \mathrm{HPO}_{4}$; Solution C contained, in $400 \mathrm{ml}$ aqua dest., $20 \mathrm{~g}$ Biomatic type BRC AB agar. The following stock solutions were prepared separately, sterilized by filtration and added to a final volume of $1 \mathrm{l}$ medium: $5 \mathrm{ml} 0.2 \% \mathrm{FeCl}_{3} \times 6 \mathrm{H}_{2} \mathrm{O}, 5 \mathrm{ml}$ $0.35 \% \mathrm{MnCl}_{2} \times 4 \mathrm{H}_{2} \mathrm{O}, 50 \mathrm{ml} 10 \% \mathrm{Na}_{2} \mathrm{~S}_{2} \mathrm{O}_{3} \times 5 \mathrm{H}_{2} \mathrm{O}$, $10 \mathrm{ml} 0.12 \% \mathrm{Na}_{2} \mathrm{~S} \times 9 \mathrm{H}_{2} \mathrm{O}, 10 \mathrm{ml} 5 \% \mathrm{NaHCO}_{3}, 0.1 \mathrm{ml}$ $0.15 \%$ yeast extract (Merck), $1 \mathrm{ml}$ trace element solution TET2 (Podgorsek \& Imhoff 1999), $1 \mathrm{ml}$ vitamin solution VA (Imhoff 1988).

For THSTh medium, $0.7 \mathrm{~g}$ sodium acetate was added to Solution $\mathrm{B}$, and the $\mathrm{NaHCO}_{3}$ was omitted.

Determination of cell numbers and protein content. Total bacterial numbers were determined by epifluorescence microscopy of acridine-orange-stained bacteria on black polycarbonate filters (Poretics). Viable numbers of SOB were obtained by streaking dilution series on THSTh and THSTa agar plates and then counting the colonies after growth.

Chemical analyses. Chemical parameters were determined in all hydrothermal fluids taken from the seafloor and plume waters, as well as in fluid samples and cultures used for activity measurements. For determination of sulfide, aliquots were taken immediately after sampling and fixed in gas-tight tubes containing 5 $\mathrm{ml} 2 \% \mathrm{Zn}$-acetate. Concentrations of sulfide were determined photometrically by methylene blue formation (absorbance at $668 \mathrm{~nm}$ ) according to Pachmayr (1960).

For the determination of all chemical components, except sulfide and elemental sulfur, samples and culture fluids were filtered through a $0.2 \mu \mathrm{m}$ pore size cellulose acetate filter (Sartorius). Nitrate, phosphate, sulfate, sulfite and thiosulfate were separated by ion chromatography using an anion exchange column (Dionex ionpack-AS4A, 250/4 mm, Dionex) and eluted with $1.7 \mathrm{mM} \mathrm{NaHCO} 3+1.8 \mathrm{mM} \mathrm{Na}_{2} \mathrm{CO}_{3}$ (flow rate $2 \mathrm{ml} \mathrm{min}{ }^{-1}$ ). Thiosulfate and tetrathionate were separated by ion-pair chromatography (Dionex ionpackNS1, 250/4 mm) and eluted with $2 \mathrm{mM}$ tetrabutyl ammonium hydroxide (TBAOH) $0.88 \mathrm{mM} \mathrm{Na}_{2} \mathrm{CO}_{3}$,

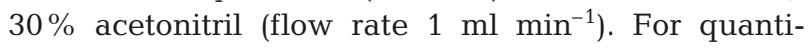
tative analyses, suppressed conductivity and UVabsorbance at 215 and $254 \mathrm{~nm}$ were used for detection, and calculations were made with the Dionex software (Dionex Ai 450, Release 3.32) as described earlier (Podgorsek \& Imhoff 1999). Because these methods required the dilution of seawater samples, the minimum concentrations that could be detected in the fluids were $0.1 \mu \mathrm{M}$ thiosulfate, $1 \mu \mathrm{M}$ sulfite and $0.5 \mu \mathrm{M}$ tetrathionate.

Elemental sulfur was determined according to Rabenstein et al. (1995). One $\mathrm{ml}$ of the sample was extracted for $12 \mathrm{~h}$ with $2 \mathrm{ml}$ petrol ether. Analysis of the elemental sulfur was carried out on the Dionex IC system using a Lichrospher 100 RP-18 column (Merck) and $95 \%$ methanol as eluent. The sulfur content was measured by UV-absorbance at $254 \mathrm{~nm}$.

Measurements of thiosulfate oxidation. Thiosulfate oxidation was measured in the hydrothermal fluids of Stns HBS84 and HBS90 under variable conditions immediately after sampling. Bacteria from $500 \mathrm{ml}$ original fluid were concentrated by filtration on $0.2 \mu \mathrm{m}$ cellulose acetate filters (Sartorius) and resuspended in $50 \mathrm{ml}$ original fluid. In the first set of measurements, thiosulfate $(1 \mathrm{mM})$ was added, and in the second set, thiosulfate $(1 \mathrm{mM})$ plus acetate $(0.3 \mathrm{mM})$ was added. Two subsets of the samples were incubated at 4 and $10^{\circ} \mathrm{C}$, respectively, for $72 \mathrm{~h}$ under aerobic conditions in the dark on a rotary shaker $(100 \mathrm{rpm})$. At intervals of 6 to $8 \mathrm{~h}$ samples were taken, filtered through $0.2 \mu \mathrm{m}$ pore size cellulose acetate filters and frozen at $-20^{\circ} \mathrm{C}$ until use for chemical analyses.

Bacterial oxidation of thiosulfate by pure cultures was determined in liquid THSTh medium with $1 \mathrm{mM}$ thiosulfate and $0.3 \mathrm{mM}$ acetate after $7 \mathrm{~d}$ incubation at $20^{\circ} \mathrm{C}$. In order to reduce the background concentration of sulfate in these experiments, the magnesium sulfate of MSM was replaced by equimolar amounts of magnesium chloride. Aliquots were taken for analyses of elemental sulfur and the other sulfur compounds. After sterile filtration, the latter samples were frozen at $-20^{\circ} \mathrm{C}$ until analysis. Rates of thiosulfate oxidation were related to the protein content of the bacterial cultures. Protein was determined according to Bradford (1976) by photometric detection at $595 \mathrm{~nm}$.

Fatty-acid analysis. Fatty acid analysis was carried out essentially as outlined in the standardized procedures of the Microbial Identification System (MIS; MIDI Incorp.). Growth conditions were slightly modified. Agar media contained, per liter, $3 \mathrm{~g}$ trypticase soy broth (Becton Dickinson), $5 \mathrm{~g} \mathrm{Na}_{2} \mathrm{~S}_{2} \mathrm{O}_{3} \times 5 \mathrm{H}_{2} \mathrm{O}, 1 \mathrm{ml}$ vitamin solution VA (Imhoff 1988), $1 \mathrm{ml}$ TET2 and $15 \mathrm{~g}$ agar in artificial sea water of $0.5 \%$ salinity. Final $\mathrm{pH}$ was 7.2 . Plates were incubated at $28^{\circ} \mathrm{C}$ for 3 to $7 \mathrm{~d}$. Harvesting of cells, extraction procedures and gas chromatographic analysis were essentially made as described by Thiemann \& Imhoff (1996).

Extraction of genomic DNA. DNA was extracted using the QIAamp extraction Kit (Qiagen) according to the manufacturer's manual. Hydrothermal and plume fluids were concentrated on $0.2 \mu \mathrm{m}$ polycarbonate filters (VKI Water Quality Institute, Hoersholm) and frozen at $-20^{\circ} \mathrm{C}$ until further use. Sample volumes 
were used ( 0.5 to 2.01$)$ that contained $10^{6}$ to $10^{7}$ bacteria. Pieces of each filter were used for DNA extraction.

DNA was also extracted from experiments set up to test the effect of thiosulfate upon the bacterial communities of the environmental samples. The fluid samples were supplemented with $5 \mathrm{mM}$ thiosulfate and incubated for 2 to $3 \mathrm{wk}$ under elevated $\mathrm{CO}_{2}$ pressure (0.5 bar) at room temperature on a rotary shaker, in order to specifically support thiosulfate-oxidizing bacteria. Prior to incubation and thereafter, bacteria from these fluids were concentrated by centrifugation $(10 \mathrm{~min}$ at $5000 \times g)$ and used for DNA analyses.

Bacterial diversity and phylogenetic analysis. For the analysis of eubacterial diversity using 16S rDNA sequences, universal eubacterial primers corresponding to the nucleotide positions 9 to 27 (Primer 5'-start) and 1387 to 1368 (Primer 3 '-1387) according to the Escherichia coli enumeration were used (see Marchesi et al. 1998). PCR amplification and double gradient DGGE, with subsequent sequencing of individual bands, was performed according to Petri \& Imhoff $(2000,2001)$. In addition, $16 \mathrm{~S}$ rDNA primers were designed with specificity for sulfur-oxidizing bacteria, previously isolated from hydrothermal systems using ARB (O. Strunk, W. Ludwig: ARB: a software environ- ment for sequence data. Technische Universität München, Munich, available at www.bio.chemie.tumuenchen.de/pub/ARB/). These primers are listed in Table 2 and were used in PCR reactions in combination with Primer 5'-start or Primer 3'-1387. For double gradient DGGE analysis, PCR products of approx. $500 \mathrm{bp}$ were obtained with eubacterial Primers 5'-907 and 3'1387 (plus a GC-clamp), according to E. coli enumeration. All primers were synthesized by MWG-Biotech.

Sequences were compared to those in the EMBL database using the FastA search program (Pearson \& Lipman 1988, Pearson 1990) in order to identify related 16S rDNA sequences. Sequences from DGGE bands and isolates were aligned with their closest relatives from the database using Clustal W, with subsequent manual correction. Missing data and gaps in more than 1 sequence were treated as missing information. Phylogenetic distances were calculated from the dataset according to the algorithm of Jukes \& Cantor (1969) by using DNADIST from the PHYLIP program package (Felsenstein 1989). Phylogenetic trees were inferred from the distance data with global rearrangements from FITCH. Bootstrap analysis of the sequences was performed with the PAUP program with 500 resamplings (Swofford \& Olson 1990, Hillis et al. 1996).

Table 2. PCR products obtained with primers specific for representatives of different groups of sulfur-oxidizing bacteria (SOB) (Thiobacillus, Halothiobacillus, Thiomicrospira, Paracoccus versutus and Pseudomonas) from plume samples (MS) and ground samples (HBS) of hydrothermal fluids of the North Fiji Basin (see 'Materials and methods' for details). -: PCR reactions with no visible product ${ }_{i}+$ : weak products; +++ : strong products; temperature anomaly $\left({ }^{\circ} \mathrm{C}\right)$ given as difference relative to background value of $2.25^{\circ} \mathrm{C}_{i}$ ratio SOB:TBN: ratio of SOB to total bacterial numbers (TBN); n.m.: not measured

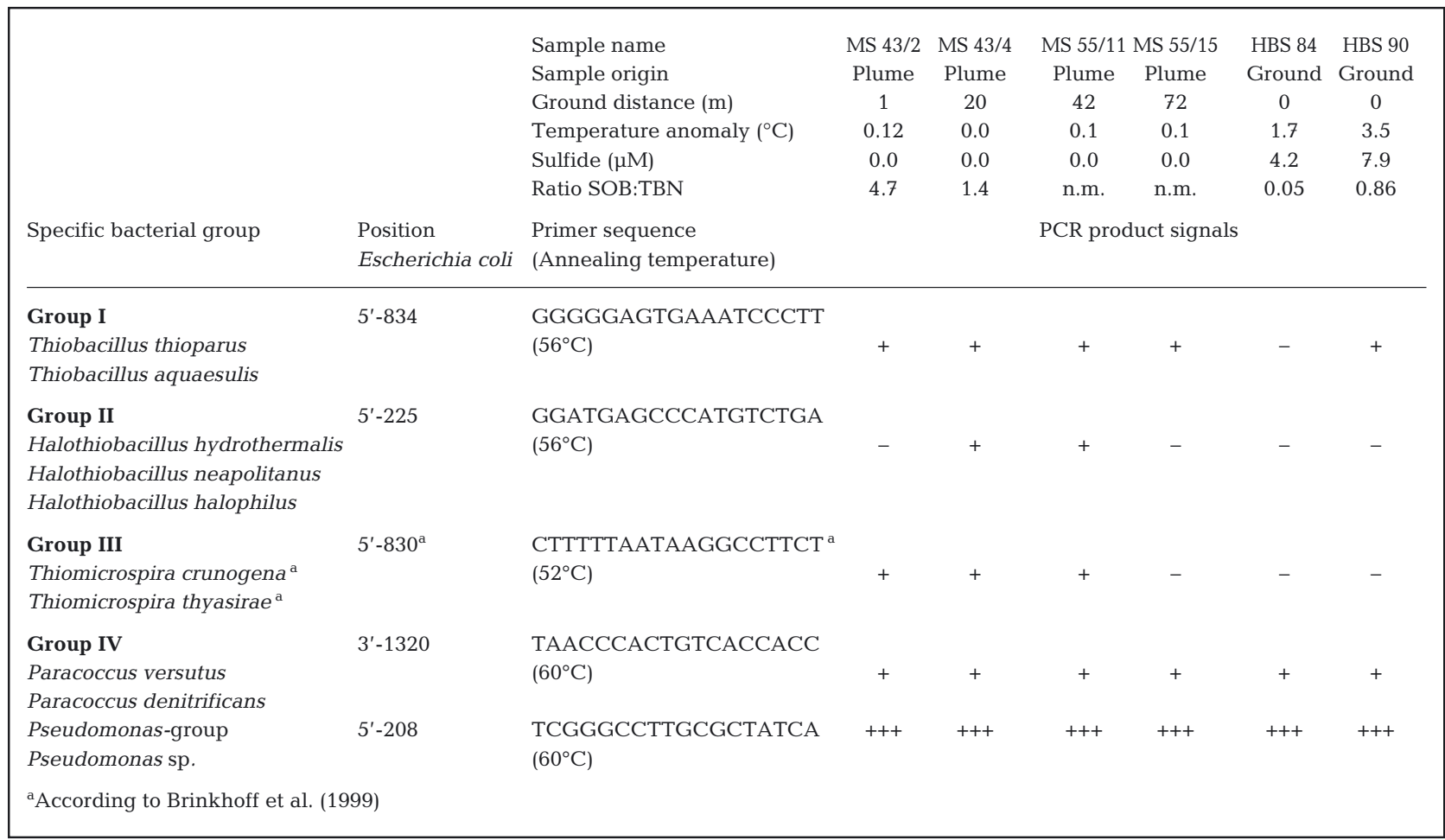




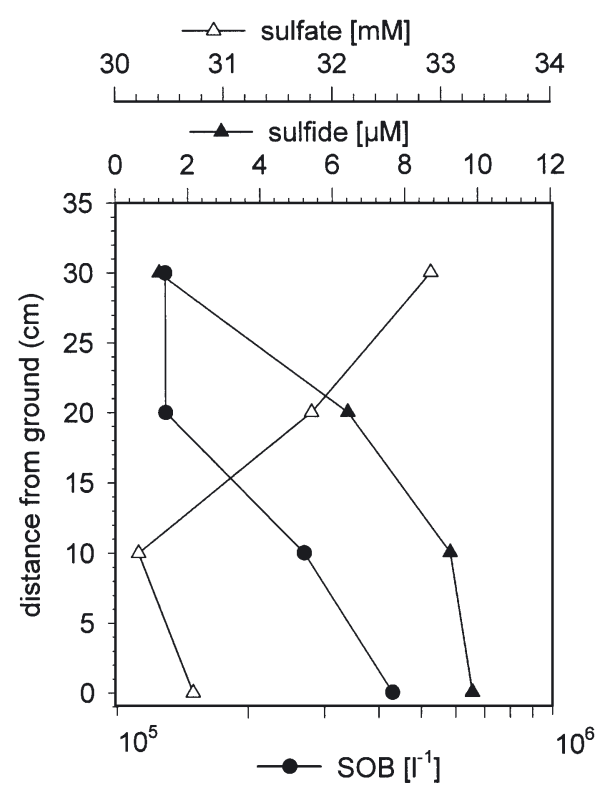

Fig. 3. Gradients of sulfide and sulfate at Stn HBS 86 reveal rapid dilution of the hydrothermal fluids within 0 and $40 \mathrm{~cm}$ from the ground. The decrease in sulfide concentrations paralleled a decrease in the counts of sulfur-oxidizing bacteria (SOB) measured as colony counts on THSTh medium

\section{RESULTS}

\section{Chemical composition of hydrothermal fluids}

Water from different MS sampling stations (Table 1) could be identified as plume water by temperature anomaly and elevated concentrations of sulfide and methane (Fig. 2). Low concentrations of sulfide, ranging from 0 to $50 \mu \mathrm{M}$, were found in the pulsing hydrothermal fluid emissions at the seafloor, but sulfide could not be detected in plume waters. The concentrations of other reduced sulfur compounds were even lower. Thiosulfate was present only in some of the HBS samples, and even then was found only in traces $(1 \mu \mathrm{M})$. Sulfite, elemental sulfur and tetrathionate were not detected. Methane concentrations from 1.1 to $39.0 \mathrm{nM}$ were found in plume water, compared to background concentrations below $0.26 \mathrm{nM}$ in the ambient sea water. In HBS samples taken close to the sea floor at hydrothermal emission sites, methane concentrations varied from 30.8 to $1580.3 \mathrm{nM}$ (Table 1). The increase of sulfide and methane concentrations with water temperature, and the concomitant decrease of sulfate and nitrate concentrations, demonstrated the hydrothermal origin and the dilution of the emitted hydrothermal fluids by the ambient seawater (Fig. 2).

At Stn HBS 86, the chemical gradients were analyzed directly in fluids above a mussel bed of Bathymodiolus brevior in distances from 0 to $40 \mathrm{~cm}$ off the sea floor. At this location, the chemical gradients were largely undisturbed by local currents, and rapid dilution of the emitted hydrothermal fluids by the ambient seawater could be recognized by the increasing concentrations of sulfate and the decreasing concentrations of sulfide. Sulfide concentrations paralleled the cell counts of SOB (Fig. 3).

\section{Oxidation of thiosulfate in hydrothermal fluid samples}

Bacterial thiosulfate oxidation was measured in fluid samples from Stns HBS 84 (Fig. 4) and HBS 90 (data not shown). Both samples yielded almost identical results. Because of the negligible content of thiosulfate in the environmental samples, they were supplemented with thiosulfate to enable the analysis of potential oxidation capabilities of the bacterial communities in them. In parallel experiments, in addition to thiosulfate, acetate was also added to support chemoorganotrophic and mixotrophic thiosulfate oxidizers limited by the available organic substrate. During $72 \mathrm{~h}$ of incubation, thiosulfate oxidation was insignificant at $4^{\circ} \mathrm{C}$. At $10^{\circ} \mathrm{C}$, and after a lag phase of $36 \mathrm{~h}$, oxidation rates reached approx. $20 \mu \mathrm{mol} \mathrm{h}{ }^{-1} \mathrm{l}^{-1}$ after $72 \mathrm{~h}$. The addition of acetate was stimulating at $10^{\circ} \mathrm{C}$ but not at $4^{\circ} \mathrm{C}$. It reduced the lag phase to approx. $30 \mathrm{~h}$ and doubled the rate of thiosulfate oxidation as measured after $72 \mathrm{~h}$ incubation. Though sulfate could not be detected as a product because of the high background value $(30 \mathrm{mM})$ in the seawater, the major part of thiosulfate evidently was oxidized to tetrathionate

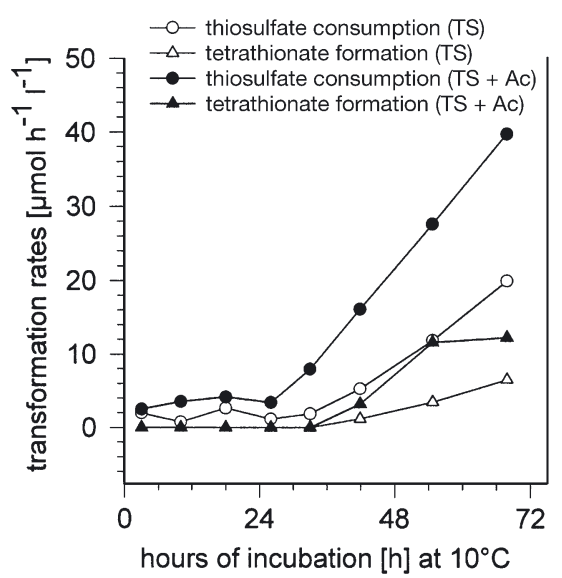

Fig. 4. Oxidation of thiosulfate $(\bullet, 0)$ and formation of tetrathionate $(\boldsymbol{\Delta}, \Delta)$ measured at $10^{\circ} \mathrm{C}$ in fluid samples of Stn HBS $84 ;(0, \Delta)$ addition of $1 \mathrm{mM}$ thiosulfate $(\mathrm{TS})$, and $(\boldsymbol{\bullet}, \mathbf{\Delta})$ addition of $1 \mathrm{mM}$ thiosulfate (TS) plus $0.3 \mathrm{mM}$ acetate (Ac). Addition of acetate almost doubled thiosulfate consumption and tetrathionate formation. At an incubation temperature of $4^{\circ} \mathrm{C}$, no transformations were detected under otherwise identical conditions 
but not to sulfate (Fig. 4). For example, after addition of thiosulfate and acetate to the fluid, $60 \%$ of the thiosulfate-sulfur was found as tetrathionate after $72 \mathrm{~h}$.

\section{Thiosulfate oxidation by pure-culture isolates}

Thiosulfate oxidation of representative new isolates from the hydrothermal waters from the Fiji Basin were analyzed in order to determine whether pure cultures produce similar oxidation products as found in environmental samples. Major oxidation products of most of these bacteria, if incubated with $1 \mathrm{mM}$ thiosulfate and $0.3 \mathrm{mM}$ acetate, were tetrathionate and sulfate, which accumulated in various proportions. Some strains almost exclusively formed tetrathionate (more than $90 \%$ of total oxidized sulfur, see Table 3). Elemental sulfur was found in traces only in 3 isolates (in GTV-B2 and GTV-B3 both related to Halomonas variabilis, see Fig. 5, and in GTV-105 related to Pseudomonas stutzeri). Sulfite was not detected in any of the cultures. These observations correlate well to the formation of large amounts of tetrathionate found in experiments with the hydrothermal fluid samples from which these bacteria were isolated.

The rates of thiosulfate oxidation varied largely between different isolates. In particular, 2 strains demonstrated high potential activities of thiosulfate oxidation, namely Strain GTV-105, which is related to
Pseudomonas stutzeri ( $798 \mu \mathrm{mol} \mathrm{d}^{-1} \mathrm{mg}_{\text {protein }}{ }^{-1}$ ) and Strain GTV-B3, which is related to Halomonas vari-

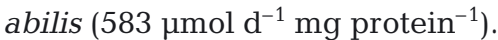

The almost exclusive formation of sulfate as an oxidation product was found only in one of our isolates, Strain HBS-103, which grows under autotrophic conditions with thiosulfate as the sole energy source, and which was phylogenetically related to Sulfitobacter mediterraneus (Fig. 5). Major portions of sulfate were also formed by Strain MS 6, which is related to Erythrobacter citreus, by Strain GTV 51g, related to Halomonas variabilis, and by Strain GTV 54, related to an unidentified deep-sea bacterium. Sulfate was the sole oxidation product of 2 chemolithotrophic bacteria to have been isolated from hydrothermal environments, and served as reference organisms in this study: Halothiobacillus hydrothermalis DSM 7121 and Thiomicrospira crunogena DSM 12353. Both these bacteria also revealed the highest rates of thiosulfate oxidation (see Table 3).

\section{Diversity of pure cultures}

Isolation of bacteria from hydrothermal fluids

Total bacterial numbers from hydrothermal bottom waters varied between $10^{7}$ and $10^{8} \mathrm{l}^{-1}$, while viable cells of bacteria grown on thiosulfate-containing THST media reached up to approx. $4 \times 10^{6}$ colony forming

Table 3. Phylogenetic affiliation of representative bacterial isolates obtained from hydrothermal fluids from the North Fiji Basin, accession numbers of $16 \mathrm{~S}$ rDNA sequences, and oxidation products of thiosulfate. Type strains of Halothiobacillus hydrothermalis and Thiomicrospira crunogena were included as reference for experiments on thiosulfate oxidation. n.m.: not measured

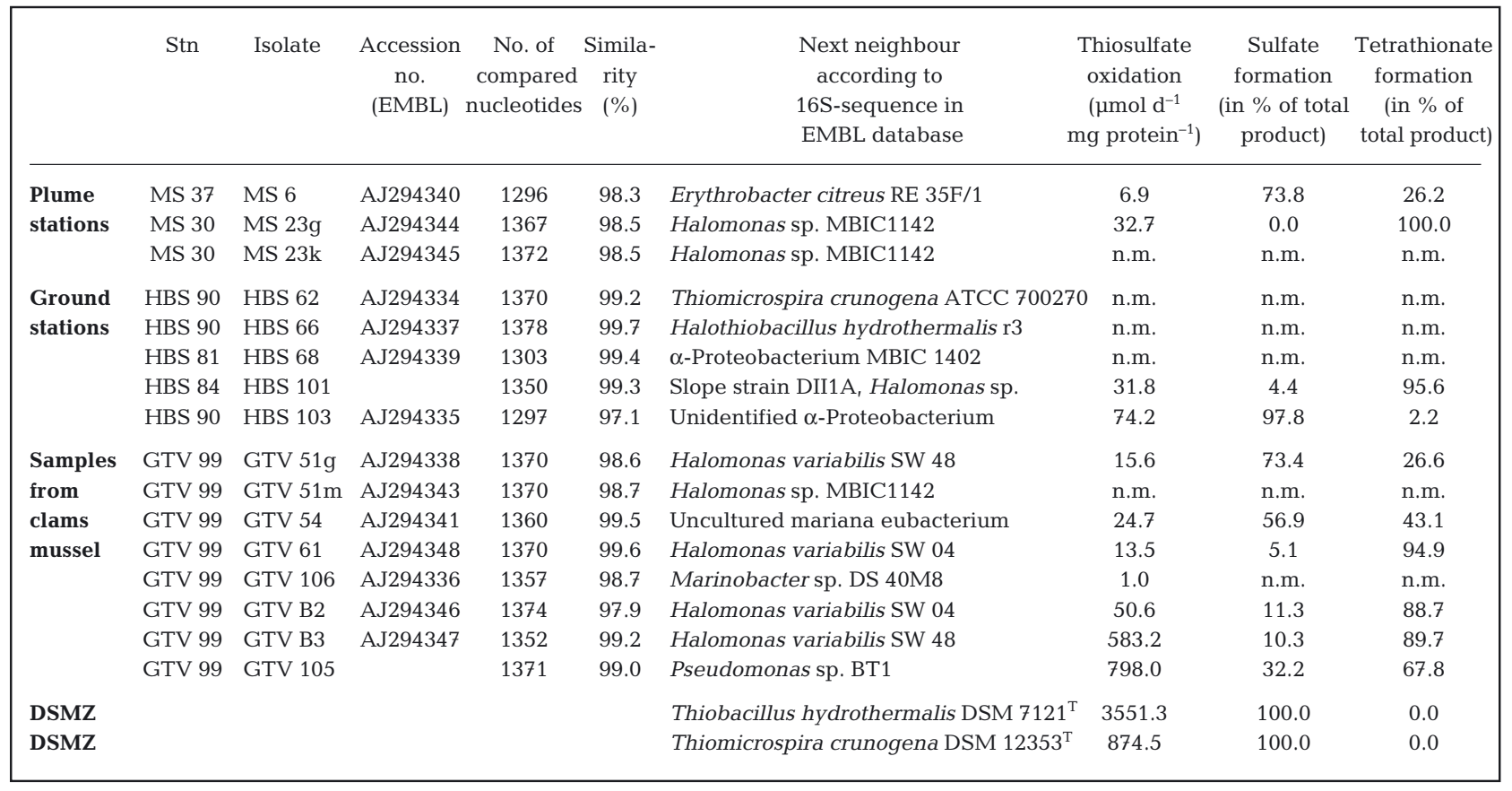




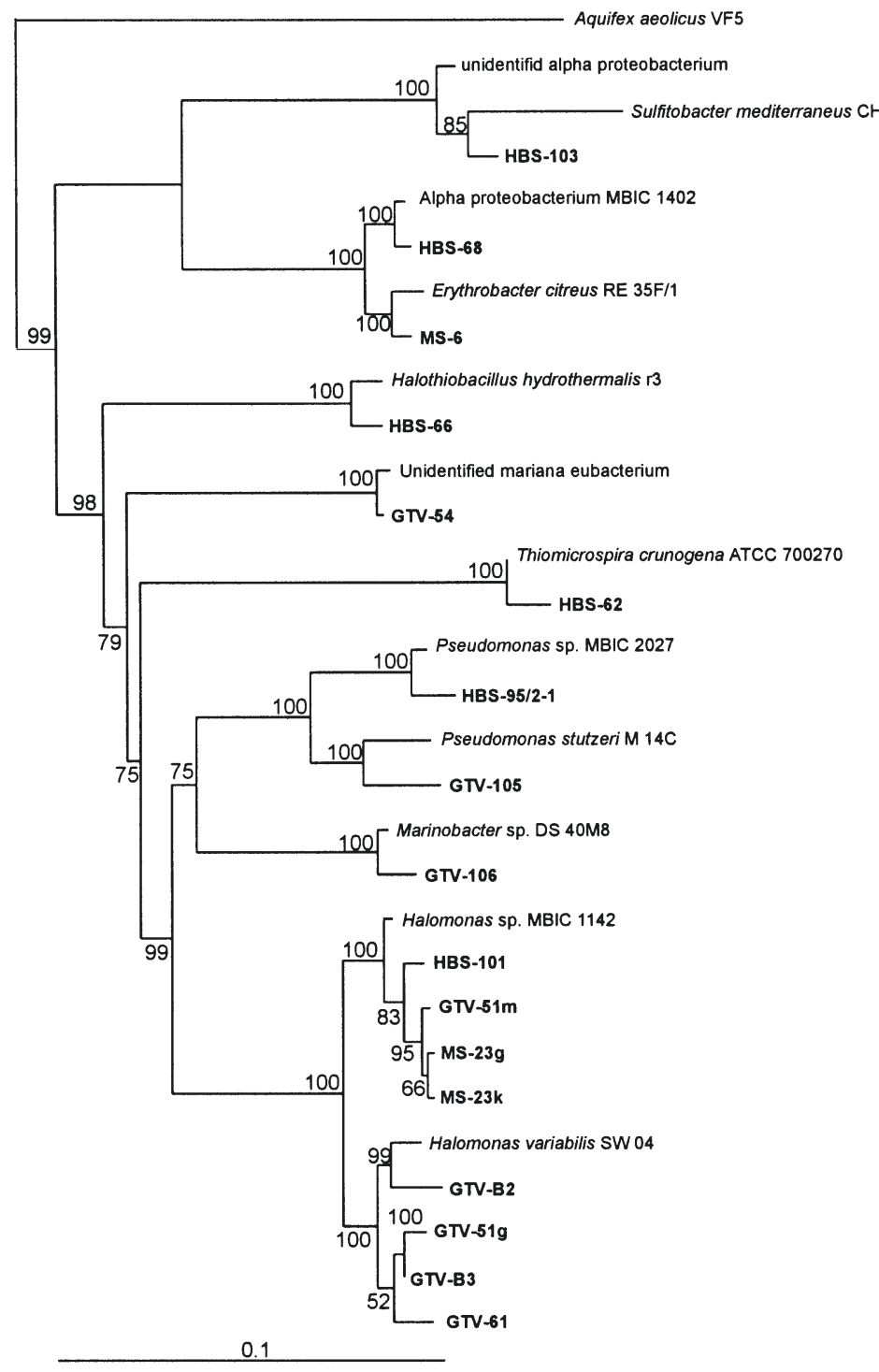

Fig. 5. Phylogenetic tree of the pure culture isolates from THST incubations of hydrothermal fluids of the North Fiji Basin based on 16S rDNA sequences with Aquifex aeolicus as an outgroup. Bootstrap values for nodes with at least $50 \%$ bootstrap support are given with 500 resamplings. Scale bar indicates the distance of the $10 \%$ sequence difference

units (cfu) $\mathrm{l}^{-1}$ in plume water. The ratio of viable SOB relative to total bacterial counts increased with higher sulfide concentrations, and cell volume also significantly increased (data not shown). Using THSTh and THSTa media, a total of 190 pure cultures were isolated after repeated streaking on agar plates.

\section{Classification by analysis of fatty acid patterns}

Because the MIS system is a useful tool to classify and group bacterial isolates according to their fatty acid composition, we have analyzed part of our isolates with this system. In order to fulfil the standard conditions that are required to compare fatty acids with each other and with the MIDI database, they were grown on tryptone soy broth (TSB) medium under standardized conditions. Three groups of strains were distinguished: (1) those strains that could be related to entries of the MIDI data base (89 strains) and for which the MIDI system provided an identification; (2) those strains that did not grow on the standard TSB medium and which were not included in the fatty acid analysis (55 strains), and (3) those strains that could not be classified according to the MIDI system, because their fatty acid patterns were not similar to any entry of the MIDI database (46 strains). Most of those strains identified by the MIDI system were identified as belonging to the genera Pseudomonas (51\%) and Brevundimonas (24\%), some were associated to the facultative autotrophic sulfur-oxidizing Paracoccus versutus (4\%), and smaller portions were related to other genera such as Rhodococcus, Nocardia, Staphylococcus, Xanthobacter and Pseudoalteromonas.

\section{S rDNA sequences from bacterial isolates}

Representative strains of the new isolates were characterized by their $16 \mathrm{~S}$ rDNA sequences. Complete 16S rDNA sequences of representative thiosulfateoxidizing isolates were obtained and compared to the EMBL database (Table 3). The majority of these isolates were $\gamma$-Proteobacteria; a few belonged to the $\alpha$-Proteobacteria (Fig. 5). Most of these isolates were associated to Halomonas, Pseudomonas and Marinobacter; others revealed relationships to Erythrobacter, Sulfitobacter and to some unidentified marine bacteria (Fig. 5). Individual strains were identified as Halothiobacillus hydrothermalis and Thiomicrospira crunogena, both of which are chemolithoautotrophic bacteria originally isolated from other hydrothermal vents (Durand et al. 1994).

\section{Bacterial diversity in hydrothermal fluids}

16S rDNA sequences from environmental samples

DNA was extracted from hydrothermal waters prior to incubation with thiosulfate (representing the bacterial community under in situ conditions) and after incubation for $2 \mathrm{wk}$. 16S rDNA sequences were obtained after PCR with eubacterial primers and separation of the products by DGGE. DGGE band patterns were compared from samples prior and after incubation. Most of the DGGE bands were present in fluids prior 
to incubation and thereafter. Changes observed during incubation were, in many instances, of qualitative nature and led to an increase or decrease of the intensity of bands found in the environmental sample. Many of the sequences obtained were associated to the same phylogenetic groups as bacterial isolates from these fluids (Figs. $5 \& 6$ ). This is, in particular, true for those associated to Marinobacter, Pseudomonas and Sulfitobacter species. Organisms related to Halothiobacillus and Halomonas were also detected in fluid samples and present among the isolates. Representatives related to Thiomicrospira and Erythrobacter were isolated in culture, but were not detected in the sequences determined from DGGE bands. On the other hand, a greater number of sequences from DGGE bands was associated to the Cytophaga/Flavobacterium group and to Cyclobacterium marinum, although these bacteria were not found among the isolates.

Specific primers for chemolithotrophic SOB from hydrothermal environments

16S rDNA sequences from chemolithoautotrophic $\mathrm{SOB}$, known to occur at hydrothermal vent systems, were used to design specific primers for the direct detection of SOB in the hydrothermal fluids (Table 2). These primers were applied to DNA extracted from plume waters (MS) and hydrothermal fluid emissions from the sea floor (HBS). By using 4 different sets of primers with specificity for different $\mathrm{SOB}$, chemolithoautotrophic SOB were detected in most plume samples. Whereas in the HBS samples Types I and IV SOB (Thiobacillus thioparus and Paracoccus versutus) were found, in the hydrothermal plumes sampled by MS55 and MS43 all 4 types (including also Halothiobacillus and Thiomicrospira) were found (Table 2).

\section{DISCUSSION}

The warm hydrothermal vents in the LHOS field of the North Fiji Basin investigated in this study are characterized by temperatures of 0 to ca. $8^{\circ} \mathrm{C}$ above ambient levels, indicating intensive mixing of the hydrothermal fluids before they leave the sea bottom. Nonetheless, the vent sites can be clearly recognized by patches of mussels settling around the sites of emanation, and hydrothermal plumes can be detected due to temperature anomalies and chemical parameters up to $100 \mathrm{~m}$ above the sea ground. The concentration of methane was found to be a good indicator of the hydrothermal origin of the fluids, due the relative stability of this compound, chemically as well as biologically. Due to the intensive mixing of hydrothermal

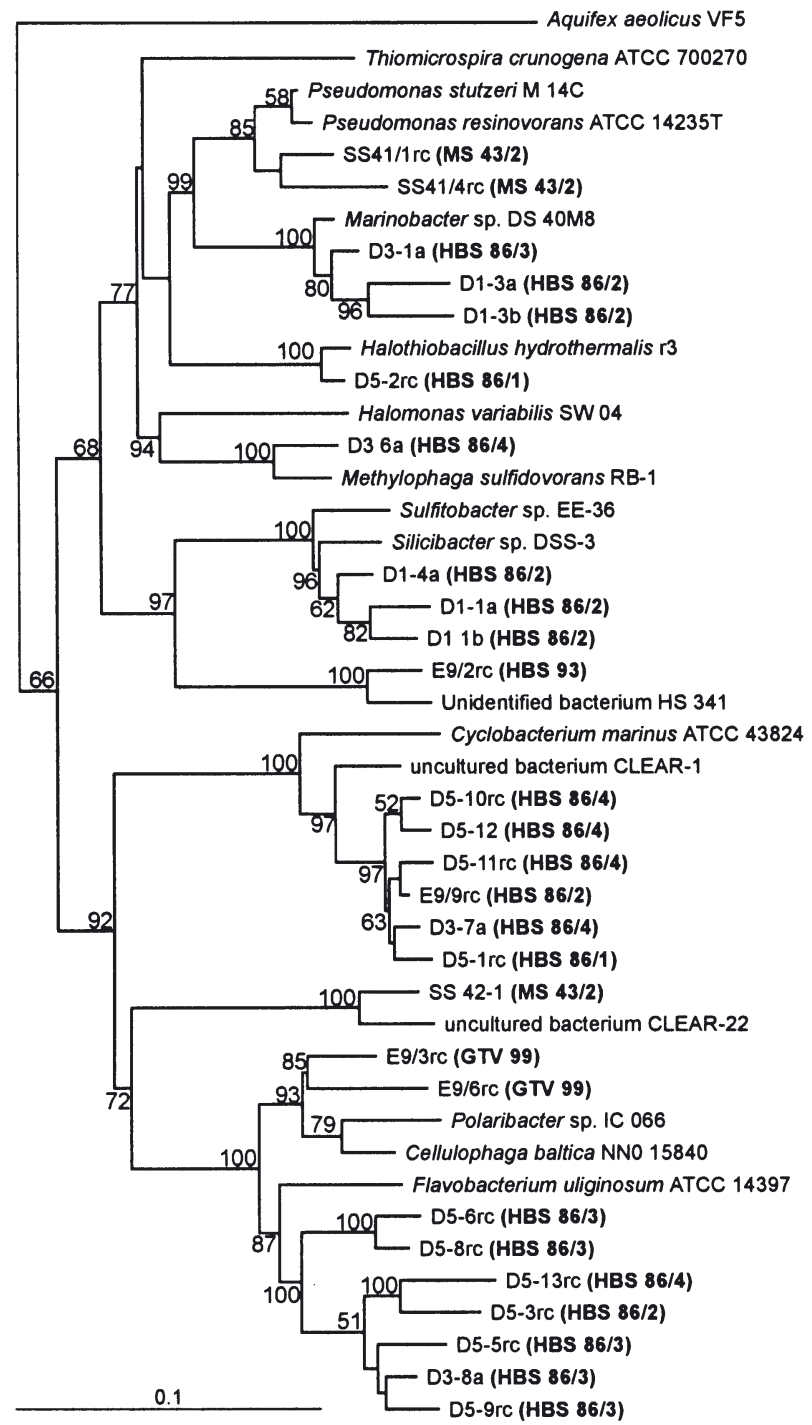

Fig. 6. Phylogenetic tree of DGGE bands derived from environmental samples as well as incubations with thiosulfate (the sample source is shown in brackets). Calculations are based on 16S rDNA fragments of approx. $400 \mathrm{bp}$. Sequences from organisms related to the environmental sequences were included as references. Aquifex aeolicus was defined as the outgroup. Bootstrap values for nodes with at least $50 \%$ bootstrap support are given with 500 resamplings. Scale bar

indicates the distance of the $10 \%$ sequence difference

fluids below ground, and possible chemical and biological reactions therein, the sulfide concentrations in the bottom water of the LHOS field (taken with HBS) were quite low, and intermediate oxidation products such as thiosulfate and tetrathionate were not detected in the hydrothermal fluids. This clearly indicates that most of the reduced sulfur compounds present in the elevating hydrothermal fluids have either been precipitated with trace metals or have been oxidized to sulfate prior to release of the fluids from the sea floor. 


\section{Thiosulfate oxidation}

Though negligible concentrations of thiosulfate were found in the hydrothermal fluids, it was oxidized at considerable rates once added to them. The rates of thiosulfate oxidation were significantly influenced by temperature, and were negligible at ambient seawater temperatures $\left(4^{\circ} \mathrm{C}\right)$ compared to those at $10^{\circ} \mathrm{C}$. This gives reason to assume that reduced sulfur compounds are only readily oxidized in the elevated temperature range of hydrothermal vents compared to ambient deep-sea waters. Strong stimulation due to the addition of thiosulfate indicated apparent substrate limitation for sulfur oxidation to occur in hydrothermal waters. Additional stimulation of thiosulfate oxidation by acetate strongly points to the chemoheterotrophic potential of bacteria active in thiosulfate oxidation, and to the additional limitation of their activities by the carbon substrate. Under both conditions, the major oxidation product of thiosulfate was tetrathionate. Because tetrathionate is known as a major oxidation product of thiosulfate in facultatively chemoautotrophic and chemoheterotrophic SOB (Sorokin 1996, Podgorsek \& Imhoff 1999, Sorokin et al. 1999), this result is an additional indication of the significant role of mixotrophic and facultatively chemoheterotrophic SOB in these hydrothermal fluids.

\section{Diversity studies}

In order to cultivate thiosulfate-oxidizing bacteria, samples of hydrothermal waters were incubated on agar plates with media specifically designed for autotrophic and hetero-/mixotrophic sulfur bacteria. Characterization of these isolates by fatty acid analysis and by $16 \mathrm{~S}$ rDNA sequences revealed the presence of several distinct bacterial groups of the $\alpha$ - and $\gamma$-Proteobacteria in the hydrothermal fluids. Although the THSTa medium was specifically designed for autotrophic bacteria such as Thiomicrospira crunogena and Halothiobacillus hydrothermalis, these bacteria were isolated only sporadically, which is taken as an indication of their low abundance in the environmental samples. Most of the isolated bacteria were obtained with a modification of this autotrophic medium, with acetate added as an organic carbon source, and were found to belong to the genera Pseudomonas, Halomonas, Brevundimonas and other heterotrophic or mixotrophic bacteria. The general picture is in agreement with that of other studies of hydrothermal vent systems of the North Fiji Basin and the Lau Basin (Durand et al. 1994).

Because even the most properly designed media have shortfalls in presenting a general view on bacteria present in an environmental sample due to their unalterable specificity, we have also applied genetic methods to analyze the diversity of bacteria and, in particular, those of sulfur bacteria in the same environmental samples. The application of primers with specificity for different phylogenetic groups of sulfuroxidizing bacteria, which includes the genera Thiobacillus, Halothiobacillus, Thiomicrospira and Paracoccus, yielded products with most of the fluid samples (Table 2), and thereby proved the presence of the major groups of SOB within these fluids.

The application of general eubacterial primers for PCR amplification with the hydrothermal fluid samples revealed the occurrence of $\alpha$ - and $\gamma$-Proteobacteria, and Cytophaga/Flexibacter/Flavobacterium as major groups, but also indicated the presence of autotrophic sulfur bacteria. Because $\alpha$ - and $\gamma$-Proteobacteria were predominant among the isolated bacteria, the analysis of environmental DNA supported these results. The situation was quite different with the Cytophaga/ Flexibacter/Flavobacterium group, which apparently could not be cultivated on the THST media used in this study, but which yielded a large number of PCR products and sequences using eubacterial primers. Similar results were obtained by Teske et al. (2000), who found major clusters of $\alpha$ - and $\gamma$-Proteobacteria together with representatives of the Cytophaga/Flavobacterium phylum in different deep-sea locations. While Teske et al. (2000) most frequently obtained isolates from the $\alpha$-Proteobacteria, the largest fraction of our isolates belongs to the $\gamma$-Proteobacteria, a phylogenetic group with prominent representatives of phototrophic and chemotrophic sulfur bacteria such as phototrophic and chemotrophic purple sulfur bacteria, including the groups Beggiatoa, Halothiobacillus, Thiomicrospira and the prominent group of endosymbiontic sulfuroxidizing bacteria (Imhoff et al. 2003).

Quite interesting, in the present study as well as in other studies, is the fact that individual species or clusters of closely related strains were found repeatedly in different hydrothermal vent systems, and apparently are widespread inhabitants of these environments. Among these are the chemoautotrophic Halothiobacillus hydrothermalis and relatives, and Thiomicrospira crunogena and relatives (Figs. 5 \& 6). Other common groups include Strain HBS-103, which is closely related to Sulfitobacter mediterraneus, to an unidentified $\alpha$-Proteobacterium, to 3 bacterial isolates from a Galapagos Rift hydrothermal vents and to 2 abyssal deepsea strains (Teske et al. 2000). Another example is found in several of our Halomonas isolates, which have 16S rDNA sequences almost identical to another isolate of Teske et al. (2000) and to Halomonas sp. MBIC 1142. Because these bacteria are active thiosulfate oxidizers, and they occur in different geographically separated hydrothermal vent habitats, it is tempting to 
conclude that their ability to oxidize reduced sulfur compounds is an important property enabling them to live and successfully compete in the hydrothermal vent environment.

\section{Role of SOB at the hydrothermal vent sites of the North Fiji Basin}

All available evidence, including oxidation experiments with hydrothermal fluids, identity, physiological properties and abundance of bacterial isolates, and genetic diversity studies, point to the ubiquitous presence of heterotrophic SOB in warm hydrothermal vents of the North Fiji Basin, and support data from other deep-sea hydrothermal vent sites (Durand et al. 1994, Teske et al. 2000). Although our media and incubation conditions were well suited for autotrophic SOB such as Halothiobacillus hydrothermalis and Thiomicrospira crunogena, these bacteria developed in low numbers compared to the mixotrophic and facultatively heterotrophic sulfuroxidizing bacteria. The abundance of potentially heterotrophic SOB in the investigated samples is supported by the large number of isolated strains, by the stimulation of thiosulfate oxidation with acetate, by the production of tetrathionate as major oxidation product in environmental samples, and also by the genetic analyses of the bacterial communities. It was suggested that heterotrophic SOB may gain a competitive advantage over other heterotrophic bacteria, and also over obligate autotrophic SOB when sulfide and dissolved organic carbon occur simultaneously (Wirsen et al. 1986). Although elevated concentrations of dissolved organic carbon were present in the hydrothermal fluids of the Fiji Basin ( 45 to $578 \mu \mathrm{M}$, R. Seifert pers. comm.), it is not known whether these carbon compounds, or a significant fraction thereof, can serve as substrates for the SOB. The abundance of heterotrophic or mixotrophic SOB within the investigated fluids would favor the assumption that, indeed, some of this organic matter can be used by sulfur-oxidizing bacteria, and is of competitive advantage for them. In this context, observations made by Wirsen et al. (1986) are quite interesting. They analyzed the potential of chemoautotrophic growth on the basis of ribulose bisphosphate carboxylase activity measurements, and calculated that obligate chemoautotrophic bacteria reached up to $79 \%$ of the bacterial population at the $21^{\circ} \mathrm{N}$ East Pacific Rise (Baja California) (Wirsen et al. 1986). This high number was found, however, directly in fluids of a warm vent opening, whereas at the base of the smoker, less than $4 \%$ chemoautotrophic bacteria occurred. Thus, accumulating evidence points to an increasing importance of chemoheterotrophic, and potentially mixotophic, bacteria in sulfur oxidation at the moderate temperature range of hydrothermal vents.

Acknowledgements. The financial support of these studies by the German Federal Ministry of Bildung und Forschung (Grant 03G0134E) is gratefully acknowledged.

\section{LITERATURE CITED}

Baross JA, Deming JW (1995) Growth at high temperatures: isolation and taxonomy, physiology, and ecology. In: Karl DM (ed) The microbiology of deep-sea hydrothermal vents. CRC Press, Boca Raton, FL, p 169-218

Bradford MM (1976) A rapid and sensitive method for the quantitation of microgram quantities of protein utilizing the principle of protein-dye binding. Anal Biochem 72: $248-254$

Brinkhoff T, Sievert SM, Kuever J, Muyzer G (1999) Distribution and diversity of sulfur-oxidizing Thiomicrospira spp. at a shallow-water hydrothermal vent in the Aegean Sea (Milos, Greece). Appl Environ Microbiol 65:3843-3849

Butterfield DA, Jonasson IR, Massoth GJ, Feely RA and 6 others (1997) Seafloor eruptions and evolution of hydrothermal fluid chemistry. Phil Trans R Soc Lond A 355: 369-386

Durand P, Benyagoub A, Prieur D (1994) Numerical taxonomy of heterotrophic sulfur-oxidizing bacteria isolated from southwestern Pacific hydrothermal vents. Can J Microbiol 40:690-697

Felsenstein J (1989) Phylip - phylogenetic interference package (Version 3.2). Cladistics 5:164-166

Gugliandolo C, Maugeri TL (1993) Chemolithotrophic, sulfuroxidizing bacteria from a marine, shallow hydrothermal vent of Vulcano (Italy). Geochem J 11:109-120

Gundersen JK, Jørgensen BB, Larsen E, Jannasch H (1992) Mats of giant sulphur bacteria on deep-sea sediments due to fluctuating hydrothermal flow. Nature 360:454-456

Halbach P, Koschinsky A, Seifert R, Giere O and 26 others (1999) Diffuse hydrothermal fluid activity, biological communities, and mineral formation in the North Fiji Basin (SW Pacific): preliminary results of the R/V Sonne Cruise SO-134. InterRidge News 8:38-44

Halbach P, Holzbecher E, Koschinsky A, Michaelis W, Seifert R (2001) Deep-sea hydrothermal microplume generation-a case study from the North Fiji Basin. Geo-Mar Lett 21:94-102

Hillis DM (1996) Inferring complex phylogenies. Nature 383 130-131

Imhoff JF (1988) Anoxygenic phototrophic bacteria. In: Austin B (ed) Methods in aquatic bacteriology. Wiley, Chichester, p 207-240

Imhoff JF, Sahling H, Süling J, Kath T (2003) 16S rDNA based phylogeny of sulfur-oxidizing endosymbionts in marine bivalves from cold-seep habitats. Mar Ecol Prog Ser 249: $39-51$

Jannasch HW (1989) Litho-autotrophically sustained ecosystems in the deep sea. In: Schlegel HG, Bowien B (eds) Biology of autotrophic bacteria. Science Tech Publishers, Madison, WI, p 147-166

Jeanthon C (2000) Molecular ecology of hydrothermal vent microbial communities. Antonie van Leeuwenhoek 77: $117-133$

Jukes TH, Cantor CR (1969) Evolution of protein molecules. In: Munro H (ed) Mammalian protein metabolism. Academic Press, New York, p 21-132 
Karl DM (1995) Ecology of free-hydrothermal vent microbial communities. In: Karl DM (ed) The microbiology of deep-sea hydrothermal vents. CRC Press, Boca Raton, FL, p 35-124

Koschinsky A, Seifert R, Halbach P, Bau M, Brasse S, De Carvalho LM, Fonseca NM (2002) Geochemistry of diffuse low-temperature hydrothermal fluids in the North Fiji Basin. Geochim Cosmochim Acta 66:1409-1427

Marchesi JR, Sato T, Weightman AJ, Martin TA, Fry JC, Hiom SJ, Wade WG (1998) Design and evaluation of useful bacterium-specific PCR primers that amplify genes coding for bacterial 16S rRNA. Appl Environ Microbiol 64:795-799

Mattison RG, Abbiati M, Dando PR, Fitzsimons MF, Pratt SM, Southward AJ, Southward EC (1998) Chemoautotrophic microbial mats in submarine caves with hydrothermal sulphidic springs at Cape Palinuro, Italy. Microb Ecol 35: $58-71$

Moyer CL, Dobbs FC, Karl DM (1994) Estimation of diversity and community structure through restriction fragment length polymorphism distribution analysis of bacterial 16S rRNA genes from a microbial mat at an active, hydrothermal vent system, Loihi Seamount, Hawaii. Appl Environ Microbiol 60:871-879

Muyzer G, Teske A, Wirsen CO, Jannasch HW (1995) Phylogenetic relationships of Thiomicrospira species and their identification in deep-sea hydrothermal vent samples by denaturing gradient gel electrophoresis of $16 \mathrm{~S}$ rDNA fragments. Arch Microbiol 164:165-172

Naganuma T, Seki H (1994) Microbial populations of hydrothermal fluid and plumes in the North Fiji Basin with reference to chemosynthesis. Mar Geol 116:243-253

Naganuma T, Otsuki A, Seki H (1989) Abundance and growth rate of bacterioplankton community in hydrothermal vent plumes of the North Fiji Basin. Deep-Sea Res 36: 1379-1390

Nelson DC, Fisher CR (1995) Chemoautotrophic and methanotrophic endosymbiotic bacteria at deep-sea vents and seeps. In: Karl DM (ed) The microbiology of deep-sea hydrothermal vents. CRC Press, Boca Raton, FL, p 125-168

Pachmayer F (1960) Vorkommen und Bestimmung von Schwefelverbindungen in Mineralwasser. $\mathrm{PhD}$ thesis, University of Munich

Pearson WR (1990) Rapid and sensitive sequence comparison with FAST and FASTA. Methods Enzymol 183:63-98

Pearson WR, Lipman DJ (1988) Improved tools for biological sequence analysis. Proc Natl Acad Sci USA 85:2444-2448

Petri R, Imhoff JF (2000) The relationship of nitrate reducing bacteria on the basis of narH gene sequences and comparison of narH and 16S rDNA based phylogeny. Syst Appl

Editorial responsibility: Otto Kinne (Editor),

Oldendorf/Luhe, Germany
Microbiol 23:47-57

Petri R, Imhoff JF (2001) Genetic analysis of sea-ice bacterial communities of the Western Baltic Sea using an improved double gradient method. Polar Biol 24:252-257

Podgorsek L, Imhoff JF (1999) Tetrathionate production by sulfur oxidizing bacteria and the role of tetrathionate in the sulfur cycle of Baltic Sea sediments. Aquat Microb Ecol 17:255-265

Polz MF, Cavanaugh CM (1995) Dominance of one bacterial phylotype at a Mid-Atlantic Ridge hydrothermal vent site. Proc Natl Acad Sci USA 92(16):7232-7236

Rabenstein A, Rethmeier J, Fischer U (1995) Sulphite as intermediate sulphur compound in anaerobic sulphide oxidation to thiosulphate by marine cyanobacteria. Z Naturforsch 50c:769-774

Reysenbach AL, Longnecker K, Kirshtein J (2000) Novel bacterial and archaeal lineages from an in situ growth chamber deployed at a mid-Atlantic ridge hydrothermal vent. Appl Environ Microbiol 66:3798-3806

Sievert SM, Brinkhoff T, Muyzer G, Ziebis W, Kuever J (1999) Spatial heterogeneity of bacterial populations along an environmental gradient at a shallow submarine hydrothermal vent near Milos Island (Greece). Appl Environ Microbiol 65:3834-3842

Sorokin DY (1996) Oxidation of sulfide and elemental sulfur to tetrathionate by chemoorganotrophic bacteria. Microbiology 65:5-9

Sorokin DY, Teske A, Robertson LA, Kuenen JG (1999) Anaerobic oxidation of thiosulfate to tetrathionate by obligately heterotrophic bacteria, belonging to the Pseudomonas stutzeri group. FEMS Microbiol Ecol 30:113-123

Swofford DL, Olsen GJ (1990) Phylogeny reconstruction. In: Hillis DM, Moritz C (eds) Molecular systematics. Sinauer Associates, Sunderland, MA, p 411-501

Taylor CD, Wirsen CO, Gaill F (1999) Rapid microbial production of filamentous sulfur mats at hydrothermal vents. Appl Environ Microbiol 65:2253-2255

Teske A, Brinkhoff T, Muyzer G, Moser DP, Rethmayer J, Jannasch HW (2000) Diversity of thiosulfate-oxidizing bacteria from marine sediments and hydrothermal vents. Appl Environ Microbiol 66:3125-3133

Thiemann B, Imhoff JF (1996) Differentiation of Ectothiorhodospiraceae based on their fatty acid composition. Syst Appl Microbiol 19:223-230

Winn CO, Karl DM (1986) Microorganisms in deep-sea hydrothermal plumes. Nature 320:744-46

Wirsen CO, Tuttle JH, Jannasch HW (1986) Activities of sulfur-oxidizing bacteria at the $21^{\circ} \mathrm{N}$ East Pacific Rise vent site. Mar Biol 92:449-456

Submitted: January 24, 2003; Accepted: September 21, 2003 Proofs received from author(s): December 29, 2003 